LUBLIN STUDIES IN MODERN LANGUAGES AND

LITERATURE 41(1), 2017, HTTP://WWW.LSMLL.UMCS.LUBLIN.PL, HTTP://LSMLL.JOURNALS.UMCS.PL

\author{
Ammar Sh. K. Al-Khafaji \\ Baghdad University \\ Baghdad, Iraq
}

\title{
A Study of Suffering and Martyrdom in Islamic Ta'ziya and Christian Passion Plays
}

\begin{abstract}
The theme of suffering and martyrdom occupies a central place in the history of religion from the earliest time. In the myths of the ancient Near East, the hero is slain, but his death, then, guarantees the revival of life. Sacrifice is a means of reaching higher and loftier stages of life; the Biblical and Qur'anic story of Abraham, who so deeply trusted God that he, without questioning, was willing to sacrifice his dear son, points to the importance of such sacrifice. Greek theater, on the other hand, grew out of a religious festival, and was often concerned with the deepest questions about morality and the relationship between mortals, gods, and fate. It was theoretically a temple of the god Dionysus, with his altar in the center.

Church history is also rich in examples of art enhancing religious teaching. From the beginning of early churches through the Middle Ages and beyond, people interact with images, music, ritual symbols and drama. Mystery, Miracle, Morality, which developed successively, have led to the creation of what is called now "the passion plays of Christ". The passion play is a dramatic presentation which depicts Jesus Christ's passion, his trial, suffering, and death. It is a traditional part of Lent in several Christian denominations, particularly in Catholic tradition. The counterpart of the Christian Passion play in Islamic tradition is the "Ta'ziyeh" which means Condolence Theatre. It commemorates the martyrdom of Imam Hussein, grandson of Prophet Muhammad. As Christ gave his life as a
\end{abstract}


sacrifice for the sake of humanity, Imam Hussein is seen as having sacrificed himself for the sake of Islam. In both traditions the theme of martyrdom is celebrated through literature.

Keywords: martyrdom; Passion plays; Ta'ziya; poetic drama

\section{Introduction}

The theme of suffering and martyrdom occupies a central place in the history of religion from the earliest time. In the myths of the ancient Near East, the hero is slain, but his death, then, guarantees the revival of life. Sacrifice is a means of reaching higher and loftier stages of life; the Biblical and Qur'anic story of Abraham, who so deeply trusted God that he, without questioning, was willing to sacrifice his dear son, points to the importance of such sacrifice. Greek theater, on the other hand, grew out of a religious festival, and was often concerned with the deepest questions about morality and the relationship between mortals, gods, and fate. It was theoretically a temple of the god Dionysus, with his altar in the center.

Church history is also rich in examples of art enhancing religious teaching. From the beginning of early churches through the Middle Ages and beyond, people interact with images, music, ritual symbols and drama. Mystery, Miracle, Morality, which developed successively, have led to the creation of what is called now "the passion plays of Christ". The passion play is a dramatic presentation which depicts Jesus Christ's passion, his trial, suffering, and death. It is a traditional part of Lent in several Christian denominations, particularly in Catholic tradition. The counterpart of the Christian Passion play in Islamic tradition is the "Ta'ziyeh" which means Condolence Theatre. It commemorates the martyrdom of Imam Hussein, grandson of Prophet Muhammad. As Christ gave his life as a sacrifice for the sake of humanity, Imam Hussein is seen as having sacrificed himself for the sake of Islam. In both traditions the theme of martyrdom is celebrated through literature.

The reconnection of Church and drama was a recovery of former state of affairs which had been lost. It was a dream that came true with some modern poetic dramatists. Thus, many poetic plays were written 
with the theme of martyrdom and sacrifice in Christian traditions. In the Islamic tradition, the tragedy of Karbala inspired some modern Muslim poets to write modern poetic dramas about it. Modern poetic drama succeeded in performing a social function by dramatizing complex states of human spiritual and moral beings and it was the fruit of the seeds planted by Christ passion plays and Islamic T'azyia. It is the role of the poetic plays to show the true meaning of martyrdom and sacrificing one's self to give life to others. Making use of the stories of hundreds of martyrs who sacrificed their lives defending the peaceful life of their countries against the terrorists who have killed life and destroyed peace. It is a suitable time for the writers of poetic drama to show through their work the difference between the true meaning of martyrdom and the deformed one.

2. A historical perspective: ancient rituals of martyrdom and sacrifice A historical perspective can be useful to trace the cosmological theme of birth and renewal. The concept of Martyrdom and sacrifice is as important in the pagan creed as it is in the recognized established human religions like Christianity and Islam. Drama is linked to religious rituals in earlier stages of all civilizations. The art of drama, like all arts, was in its initial stages closely connected to religion. ${ }^{1}$ Aristotle in his Poetics argues that drama developed from the joys which people find in mimeses and that the blending of the developed mimetic actions with religion gave rise to rituals, and ritual, in turn, to drama. ${ }^{2}$ Human sacrifices were characteristics of many early pagan religions. ${ }^{3}$ In the myths of the ancient Near East "the hero is slain, but his death, then, guarantees the revival of life." "The category of "dying and rising gods', according to James G. Frazer, applies to a set of

\footnotetext{
${ }^{1}$ David Daiches, A Critical History of English Literature: from the Beginning to the Sixteenth Century (New York: The Roland Press Co., 1965), 209.

2 James Redmond, Drama and Religion (New York: Cambridge University Press, 2008), 67.

${ }^{3}$ Arthur Weigall, Paganism in Our Christianity (New York: G.P Putnam's Sons, 1928), 164.

${ }^{4}$ Ibid.
} 
young male deities who represent the annual death and resurrection. In the ancient world, there was a very widespread faith that the sufferings and deaths of gods can be useful for human being. ${ }^{5}$ Deities like Dionysos, Herakles, Mithra, Osiris, Adonis, Attis and Tammuz were savior-gods who redeem mankind. ${ }^{6}$

People of Egypt and Mesopotamia used to represent the yearly process of decay and revival of life in their myths of gods who annually die and rise again from the dead; "in name and details the rites varied from place to place: in substance, they were the same." John Gassner $^{8}$ argues that a passion play is a term which is used widely to indicate dramatic rites dealing with the death and resurrection of a god, and more specifically and narrowly in later ages, to the dramatization of the suffering and crucifixion of Christ. ${ }^{9}$

3. Martyrdom and suffering in Islamic and Christian traditions: of Christ's Passion Plays and of Imam Hussein's Ta'ziyeh

Sacrifices can mean reaching higher and loftier stages of life. Abraham had a deep faith in God that he was ready to sacrifice his beloved son. Just as the life of Christ and biblical events play a central role in the development of commemorative liturgical and biblical

\footnotetext{
5 Sir James George Frazer (1854-1941), was a Scottish social anthropologist influential in the early stages of the modern studies of mythology and comparative religion. He is often considered one of the founding fathers of modern anthropology. His most famous work, The Golden Bough (1890), documents and details the similarities among magical and religious beliefs across the globe (https://en.wikipedia.org/wiki/James_George_Frazer, accessed May 20, 2013).

${ }^{6}$ James G. Frazer, The Golden Bough (New York: Oxford University Press Inc., 1998), 302.

${ }^{7}$ Ibid., 366.

${ }^{8}$ John Gassner (1903-1967) was born in Hungary and immigrated to the United States in 1911. He is a dramatic critic who taught dramatic criticism and playwriting at many colleges and universities in 1956 he joined the faculty of the Yale School of Drama as the Sterling Professor of Playwriting, a position he held until his death (http://www.oxfordreference.com/view/10.1093/oi/authority.20110803095844204, accessed May 20, 2013).

${ }^{9}$ Collier Encyclopedias, $6^{\text {th }}$ ed., s.v. "Passion play", John Gassner.
} 
drama or what is called "Passion plays of Christ" within Christianity, a major historical event which is the martyrdom of Imam Hussein, the grandson of the prophet of Islam, Mohammad, has become the central inspiration for the development of the Islamic commemorative drama called "Ta'ziyeh." 10 Whether in Islam or Christianity, Passion plays remain as a dramatic source of inspiration, a living way to reflect on the events most central to their faith, to identify with them, and to understand them at a deeper level. The word "martyr," in both the Christian and Islamic traditions, means "witness." In this regard, "martyr" refers to a witness to the faith. The word "martyr" comes from the Greek martus, meaning "witness." Drama and Christian church have strong bonds. The two great festivals of Christmas and Easter and their celebrations play a vital role in strengthening the long lived relation between Drama and the Christian church. ${ }^{12}$

The Liturgical drama, which flourished in the Middle Ages into three types of religious plays, Passion, Miracle and Mystery, is a drama whose roots are originated in the medieval church. ${ }^{13}$ The tremendous themes and the mighty-religious passion of English Mystery and Miracle Cycles made them "dramatic both in range and spirit.",14

The word "passion" comes from a Latin root; literally it means, "to suffer." Passion play can be defined as:

A religious play representing the trials, crucifixion, and resurrection of Jesus. Performances of such plays are recorded in various parts of Europe from the early

\footnotetext{
${ }^{10}$ John Gassner and Edward Quinn. (eds.), The Reader's Encyclopedia Of World Drama (New York: Dover Publication Inc, 2002), 494.

${ }^{11}$ Alison A. Trites, The New Testament Concept of Witness (Cambridge: Cambridge University Press, 2004), 300.

${ }^{12}$ Daiches, 209.

${ }^{13}$ J.A. Cuddon, The Penguin Dictionary of Literary Terms and Literary Theories, rev. ed. (London: Penguin Books, 1998), s.v ."liturgical drama".

${ }^{14}$ Katherine Lee Bates, English Religious Drama (New York: Macmillan Co., 1910), 49.
} 
13th century onwards. Some of passion plays formed part of the cycle of Mystery Plays, others were performed separately, usually on Good Friday. ${ }^{15}$

By the fifteenth century, the Passion play had become somewhat degraded and was suppressed both in Germany and England because of the Protestant Reformation. ${ }^{16}$ The single exception was The Passion play of Oberammergau in Bavaria through which Passion plays survived into modern times. The Passion play of Oberammergau came into existence when the terrified survivors of Oberammergau begged God to spare their town from "The Black Death" which killed nearly one hundred of them in 1634. They made a vow to perform a passion play in their village every ten years if God saved them. The plague disappeared with no further deaths and the villagers of Oberammergau had faithfully kept their vow to the present day and the Oberammergau Passion Play has been performed virtually every decade since then. ${ }^{17}$

Almost half of Oberammergau's five thousands and two hundred men, women, and children perform in the play, and as, the passion play is the main object of their lives, they are ready to make any sacrifice for it. ${ }^{18}$ Acting in the Passion play means so much to the native of Oberammergau. For example, even the natives who leave to study or work must return a year in advance if they want to be included in the list of performers. ${ }^{19}$ In the German village of Oberammergau, both theater and life are being blended to the extent that one cannot differentiate between the two. ${ }^{20}$ There is nothing

\footnotetext{
${ }^{15}$ Chris Baldick, The Concise Oxford Dictionary of Literary Terms (Oxford: Oxford University Press, 2001), 185, s.v. "passion play."

${ }^{16}$ Martin Benham, Cambridge Guide to Theater (Cambridge: Cambridge University Press. 2000), 106.

${ }^{17}$ Janet H. Swift, The Passion Play of Oberammergau (New York: Fleming H. Revell Co., 1986), 48.

${ }^{18}$ Encyclopedia Britannica Junior, 1980 ed., s.v. "Passion Play".

${ }^{19}$ Helena Waddy, Oberammergau in the Nazi Era:The Fate of a Catholic Village in Hitler's Germany (Oxford: Oxford University Press Inc., 2010), 33.

${ }^{20}$ Encyclopedia Americana, $4^{\text {th }}$ ed., s.v. "Passion Play".
} 
sadder for the real Oberammergauer than the last day of the Passion Play; "If he had to lose all his belongings he could hardly be more depressed than at the moment, when he must take leave of those performances." ${ }^{21}$ In one of the directors' words, "no Oberammergauer can talk about the village without thinking of the play...the play is part of us. It controls the rhythm of our life." 22 The actors have their share of joy and devotion; "they are greatly agitated as the climax of their summer feelings move them to tears as they grasp each other hands, after the closing tableaux and last strain of the orchestra finale is heard."

The counterpart of the Christian Passion play in Islamic tradition is the "Ta'ziyeh" as it is called in Persia or "Tashabih" as it is called in Iraq. It is the dramatized form of martyrdom of prophet Mohammad's grandson Imam Hussein. The "Ta'ziyeh" (Tashabih) is a dramatic recreation, often entirely in verse, of selected scenes of the events of Karbala, the place where Imam Hussein was martyred. Furthermore, it is not merely an exercise in religious narration, but like the Passion Play of Christ, a performance that gives a moral lesson to the audience. $^{24}$

Jamshid Malekpour ${ }^{25}$, in his book Islamic Drama (2004), refutes misconceptions among Western theater scholars about the absence of

\footnotetext{
${ }^{21}$ Joseph Schroeder, Guide to Oberammergau And Its Passion Play. Trans. Reginald Maxse (New York: Lightning Source Incorporated, 2007), 133.

22 Don Rubin, The World Encyclopedia of Contemporary Theater (New York: Taylor and Francis Group, 2005), 45.

${ }^{23}$ Sylvia P. Jenkins, "The Oberammergau Passion Play: A Literary Study," German Life and Letters. 5 ,no.1 (October,1951), 1. http://onlinelibrary.wiley.com/doi/10.1111/j.1468-83.1951.tb01025.x/abstract (accessed May 5, 2013).

${ }^{24}$ Jamshid Malekpour is a lecturer, scholar, writer and director of Theater and Cinema and is currently an assistant professor at the Department of Mass Communication. He is the author of eight books on theater and drama, including The Islamic Drama which was published in 2004 by Taylor \& Francis in London (https://www.gust.edu.kw/jamshid_malekpour, accessed May 5, 2013).

${ }^{25}$ Jamshid Malekpour, The Islamic Drama (New York: Frank Cass Publishers, 2005), 6.
} 
an indigenous Islamic theater and affirms that Ta'ziyeh is the sole Islamic drama before the mid-nineteenth century when Western influence came to the Islamic world. He describes this type of drama as being "a ritualistic form of theater, akin to the early Greek drama, but more closely related to medieval European drama or even to the 2500 years Abydos passion play of Egypt."26 M. M. Badawi, a specialized researcher in Arab theater and drama, concludes that "Ta'ziya should more properly be viewed as an extension of religious ritual than a drama. However, its mere existence explodes the popular fallacy that Islam...is incompatible with dramatic representation."

Historical sources all agree that in the year $61 \mathrm{AH} / 680 \mathrm{CE}$, Hussein bin 'Ali bin Abi Talib, Prophet Mohammad's grandson, refused to give his allegiance to the Yazid bin $\mathrm{Mu}$ 'awiyah, who was appointed heir to the caliphate by his father, Mu'awiyah Ibn Abi Sufyan. An act was considered illegitimate because none of the preceding caliphs since the death of Mohammad was appointed by dynastic succession. ${ }^{28}$ Consequently, Al-Hussein decided to march to Karbala. Al-Hussein, his seventy-two male followers, and their women and children were surrounded and besieged by Yazid's men for three days in the desert sands of Karbala, near the banks of the Euphrates. Deprived of water during the siege, Hussein and his band were attacked by at least 10,000 Umayyad soldiers. On the tenth day of the month of Muharram (a day now commonly referred to as Ashura), Imam Hussein and his devoted seventy-two men were killed brutally.

\footnotetext{
${ }^{26}$ Ibid.

27 Mohammad Musaafa Badawi, Modern Arabic Drama in Egypt (Cambridge: Cambridge University Press, 1987), 1.

${ }^{28}$ Ali J. Hussein, "The Mourning of History and the History of Mourning: The Evolution of Ritual Commemoration of the Battle of Karbala," Comparative Studies of South Asia, Africa and the Middle East, Vol. 25, No. 1. (Jan., 2005), 78-88 (http://muse.jhu.edu/journals/cst/summary/v025/25.1hussein.html, accessed April 5, 2013).
} 
Al-Hussein's household (women and children) were taken as captives to Damascus, in addition to the severed heads of the killed. ${ }^{29}$

Islamic passion plays which are called "Ta'ziyeh" (consolation) or "tashabih" (simulated) are similar to Christian Passion plays of medieval Europe in "intent as well as in stage presentation.",30

The word Ta'ziyeh came from an Arabic root /aza/, which means condolences, mourning or sympathy. ${ }^{31}$ Although the Islamic passion plays are acted mainly in Iran and they are called Persian Passion plays, they have their roots in other Islamic countries like Iraq and Turkey.

In the words of Milla C. Riggo, "celebration of Muharram festival rites is not in themselves uniquely Persian." ${ }^{" 33}$ The patronage of the Iranian Safvis and the Qajar shahs played an important role in the development of Ta'ziyeh. Huge open-air arenas called tekiyeh were built for royally performed performances. Nasir al-Din the Qajar Shah (1848-1869) built in 1870s Takiyeh Dawlat, the Royal Theater in Tehran, which was the most famous of all the Ta'ziyeh performance spaces which surpassed that of Europe's greatest opera houses in the opinion of many Western visitors. ${ }^{34}$ Most Ta'ziyeh dramas, like the passion of Oberammergau, were originally performed outdoors at crossroads and other public places where large audiences could gather. $^{35}$

To participate in Ta'ziyeh or the Passion of Christ is to take part in a profoundly religious event filled with intense grief, lamentation and mourning where there is a lot of self-sacrifice, suffering and profound

\footnotetext{
${ }^{29}$ Ibid.

${ }^{30}$ Gassner and Quinn , 647.

${ }^{31}$ Ibid.

32 Ibid.

33 Milla C. Riggo, "Ta`ziyeh in Exile: Transformations in a Persian Tradition," Comparative Drama, Vol. 28, No. 1, (Spring 1994), 115-140 (http://connection ebscohost.com/c/articles tradition, accessed April 5, 2013).

${ }^{34}$ Gabrielle H. Cody and Evert Sprinchorn (eds.), The Columbia Encyclopedia of Modern Drama (New York: Columbia University Press, 2007), 692.

35 Josephine Helena Short, Oberammergau and the Passion Play (New York: Kessinger Publishing Co., 2005), 14.
} 
act of divine redemption. The pain which the participants can feel is the pain of Jesus and Hussein. The story of the passion play of Jesus Christ is filled with pathetic scenes, like for example,

when Jesus is whipped and then given a crown of thorns to mock the claim that he is 'King of the Jews,' and then dressed in a purple robe. Jesus carries his cross to the place of crucifixion, helped by Simon of Cyrene. Jesus is stripped and nailed to the Cross. Two criminals are crucified alongside him. After some hours the soldiers check that Jesus is dead by stabbing him in the side. Blood and water gush out. Jesus' body is taken down and buried. ${ }^{36}$

Like the passion play of Christ, Ta'ziyeh consists of a cycle of plays that represent the following heart aching events:

The journey of Hussein and his family from Madina; the capture and the murder of his envoy Muslim ... the besieging of the party; the enemy's denial of water to the crusading family for three days of scorching heat; the exploit of Abbas, a valiant half brother of Al-Hussein, who loses both hands as he desperately try to get some water from the Euphrates for the children of the holy family; the martyrdom of Hussein's nephew, Qasim, whose wedding with Hussein's daughter turns into mourning feast? The martyrdom of Hussein's two young sons, Ali Akbar and Ali Asghar..., the martyrdom of seventy two men in Hussein's camp and finally the martyrdom of Imam Hussein himself. Scenes of the captivity of the remaining women, who were carried off to Yazid in Damascus, complete the cycle. $^{37}$

The Oberammergau Passion play of Christ and Imam Hussein's Ta'ziyeh have numerous similarities between them:

Oberammergau centers on Jesus and his supporters, while the Ta'ziyeh centers on Hussein and his clan. Jesus is betrayed by the once-loyal to him, while Hussein is betrayed by the Kufans. The Christian play is devoted to the "passion" of Jesus means his suffering and gruesome death, just as Ta'ziyeh is devoted to the tragic suffering and death of Hussein and his family. A significant part of both stories deal with the grieving, as well as courage of women, whether of Mary, who

\footnotetext{
36 (http://www.bbc.co.ukreligion/religious/Christianity/history religion/religions/christianity/history/passionofchrist_1.shtml, accessed April 5, 2013).

37 Janet Afary, Kevin B. Anderson, Foucault and the Iranian Revolution (Chicago: Chicago University Press, 2005), 55.
} 
mourns the loss of her son, or of Zainab, who lives to tell the story of her brother's martyrdom. ${ }^{38}$

The Passion play of Christ and Ta'ziyeh are ritual dramas and treasures from the past which exist today. They integrate faith, civilization, history, culture, arts, music, literature and creativity. They become history in themselves. The journeys of the two were not easy, there were many struggles and challenges, but both become well known traditional and ritual art forms. They give their viewers a kind of blessed moments that leads to emotional catharsis after seeing the eternal struggle between goodness and evil, the tyrants and their victims, faith and blasphemy.

Poetic drama is the ideal means to express elevated themes; its history shows that it can surpass all difficulties to remain alive. Despite all the efforts that have been made by different political and religious institutions to prevent the performance of the poetic religious plays, the ongoing battle will continue and sooner or later such poetic plays will find their permanent place in the theater because they have become a moral necessity. Especially, in a time like ours, when the meaning of martyrdom is deformed and greatly misrepresented by terrorists who destroy the world under the name of religion. It is the role of the poetic plays to show that the true meaning of martyrdom is to sacrifice one's self to give life to others, by making use of the heritage of hundreds of martyrs who sacrificed their lives defending the peaceful life of their countries against those terrorists who have killed life and destroyed peace. The suffering of Christ and that of Imam Hussein will remain a source of inspiration for the patriotic and faithful playwrights whose boldness, fearlessness, and purposefulness have played a great role in promoting thinking and creating an awareness of the false destructive ideologies surging continuously in our violent world.

\footnotetext{
${ }^{38}$ Afary, 56a.
} 


\section{References}

Afary, J. \& Anderson, K. B. (2005). Foucault and the Iranian Revolution. Chicago: Chicago University Press.

Badawi, M. M. (1988). Modern Arabic Drama in Egypt Cambridge: Cambridge University Press.

Baldick, C. (2001). The Concise Oxford Dictionary of Literary Terms. Oxford: Oxford University Press.

Bates, K. L. (1910). English Religious Drama. New York: Macmillan Co..

Benham, M. (2000). Cambridge Guide to Theater. Cambridge: Cambridge University Press.

Cody, G. \& Sprinchorn, E. H. (eds.) (2007). The Columbia Encyclopedia of Modern Drama. New York: Columbia University Press.

Collier Encyclopedias, $6^{\text {th }}$ ed.

Cuddon, J. A. (1998). The Penguin Dictionary of Literary Terms and Literary Theories. Rev. ed. London: Penguin Books.

Daiches, D. (1965). A Critical History of English Literature: From the Beginning to the Sixteenth Century. New York: The Roland Press Co..

Encyclopedia Americana, $4^{\text {th }}$ ed.

Encyclopedia Britannica Junior, $6^{\text {th }}$ ed.

Fort, A. B. \& Kates, H. S. (1935). Minute History of the Drama. New York: Grosset $\&$ Dunlap.

Frazer, J. G. (1998). The Golden Bough. New York: Oxford University Press Inc..

Gassner, J. \& Quinn, E. (eds.) (2002). The Reader's Encyclopedia of World Drama. New York: Dover Publication Inc.

Hussein, A. J. (2005). The mourning of history and the history of mourning: The evolution of ritual commemoration of the Battle of Karbala. Comparative Studies of South Asia, Africa and the Middle East, 25(1), 78-88 (http://muse.jhu.edu/journals/cst/summary/v025/25.1hussein.html, accessed April 5, 2013).

Jenkins, S. P. (1951). The Oberammergau Passion Play: A literary study. German Life and Letters, 5(1), $1 . \quad$ (http://onlinelibrary.wiley.com/doi/10.1111/j.14680483.1951.tb01025.x/abstract, accessed May 5, 2013).

Malekpour, J. (2005). The Islamic Drama New York: Frank Cass Publishers.

Merit Student Encyclopedia, 1986. ed.

Petty, R. A. (1981). Ritual enactment of Persian Renewal. Theater Journal, 33(3), 341-354 (http://www.jstor org/discover/10.2307032?uid=2 \&uid=4\&sid=21102168398271, accessed April 5, 2013).

Redmond, J. (2008). Drama and Religion. New York: Cambridge University Press. 
Riggo, M. C. (1994). Ta`ziyeh in Exile: Transformations in a Persian Tradition. Comparative Drama, 28(1), 115-140 (http://connection ebscohost.com/c/articlestradition, accessed April 5, 2013).

Rubin, D. (2005). The World Encyclopedia of Contemporary Theater. New York: Taylor and Francis Group.

Schroeder, J. (2007). Guide to Oberammergau and Its Passion Play. Trans. Reginald Maxse. New York: Lightning Source Incorporated.

Short, J. H. (2005). Oberammergau and the Passion Play. New York: Kessinger Publishing Co.

Swift, J. H. (1986). The Passion Play of Oberammergau. New York: Fleming H. Revell Co.

Trites, A. A. (2004). The New Testament Concept of Witness. Cambridge: Cambridge University Press.

Waddy, H. (2010). Oberammergau in the Nazi Era: The Fate of a Catholic Village in Hitler's Germany. Oxford: Oxford University Press Inc..

Weigall, A. (1928). Paganism in Our Christianity. New York: G.P Putnam's Sons. 